\title{
Youth, agriculture and land reform in Zimbabwe: Experiences from a communal area and resettlement scheme in semi-arid Matabeleland, Zimbabwe
}

\author{
Vusilizwe Thebe \\ Department of Anthropology and Archaeology \\ University of Pretoria \\ P. Bag X 20 \\ Hatfield \\ 0028 \\ Pretoria \\ South Africa
}

\section{Note on Contributor}

Vusilizwe Thebe is An Associate Professor in the Department of Anthropology and Archaeology at the University of Pretoria, South Africa, with specialisation in Development Studies. His work has been organised around themes in rural development including land, landholdings and its use, the natural environment and livelihoods, and migrant labour economies. His current research is focused on the changing worker-peasantries in former labour reserves.

\begin{abstract}
:
Three decades of land reform in Zimbabwe ended in an ambiguous victory for youth. Focus on the cumulative outcome, in terms of scale and scope, led to conclusions that the exercise was a success, which obscured the resultant forms of exclusion. This article attempts to sketch an analytical context in which the dynamics of Zimbabwe's land reform may be understood. It focuses at the broader policy and societal levels, and investigates the socio-political dynamics, and their combined effects on landing the economy for youth. It highlights the challenges associated with poverty reduction through land and agriculture for a semi-proletarian youth, and suggests that a policy of agricultural modernisation is unlikely to succeed in changing the economic circumstances of young people.
\end{abstract}

Keywords: agriculture; land; land reforms; youth; Zimbabwe 
Youth have featured prominently in literature on Zimbabwe's land reforms. In an introduction of an article in Development and Change, Blair Rutherford wrote:

On the afternoon of 16 April $2000, \ldots$ a group of young men ... was driven to a commercial ... farm ... Once they arrived ... the youths ... began beating the men and women working on the farm ... As they put it at the time, they were 'symbolically occupying' the land. (2008: 74)

On the land occupations in Chiredzi District in early 2000, Chaumba, Scoones and Wolmer observed, '[t]his ostensibly chaotic space was peopled by an anarchic bunch of selfproclaimed liberation war veterans, disaffected jobless and landless youths' (2003: 534). Similarly, Bronwen Manby observed, '[w]ar veterans and youth supporters form a gang or militia of a structure of command when they invade a farm' (2002: 22). While much has been learnt from this literature on youth and land politics in Zimbabwe, here, I pay particular attention to landing the economy for young people in Zimbabwe, and in particular youth, land reform and agriculture, and the realities of young people in rural societies. I argue, based on evidence at the policy, resettlement and communal area levels that land reform could not be relied upon to provide a sustainable solution to the youth crisis in Zimbabwe. I particularly stress certain historical, political, and social dynamics that shaped the political economy of land, and while I recognise the importance of land reform in empowerment and poverty reduction, I challenge the link between agriculture and economic empowerment for youth in the context of Zimbabwe. My aim in this article is to offer an empirically grounded questioning of the 'land the economy and the economy the land' narrative, and its application to youth employment and well-being. I suggest that policy which addresses young people's economic well-being and livelihoods needs to take into account the very realities of rural youth and rural society, and move beyond concerns about the 'professionalization' of agriculture.

I rest my analysis on a selected reading of literature on the country's land reforms since independence in 1980 where I extract material specific to the policy process, and material from an extended study of young people, livelihoods and agriculture in a semi-arid communal area and resettlement area in western Zimbabwe between 2004 and 2015. I use the literature material in the third section of the article where I provide a national level analysis of the youth and land reform problem, focusing particularly on the three decades of land reform. I move from the 
national level to a local study of social, political and livelihood dynamics in the sections that follow, focusing first, on communal area dynamics at a former reserve community (Menyezwa Ward villages) in Lupane District, and young land recipients in Umguza District. I draw on life history interviews with 30 young people between 22 and 35 years. The life histories took the form of extended conversations, shaped by my question schedule but also allowing participants to delve into a range of issues about their lives, challenges, aspirations and livelihood pathways. The life histories were supplemented through material from an earlier ethnographic study on the two sites conducted between 2004 and 2006.

The article is arranged as follows: immediately following this introduction, I present the theoretical arguments that underpin my analysis, before turning my focus to the national level where I discuss the three decades of land reform in relation to the country's youth population. I then turn my attention to the micro level where I provide evidence from two case studies of differing characteristics. Here, I focus on worker-peasant dynamics and their impact on 'landing the economy for young people'.

\section{Youth, agriculture and migrant labour societies}

Recent years have seen a proliferation of scholarship and other initiatives relating to young people and their economic development, particularly in developing countries. At the core of these initiatives is a range of ideas about the youth problem and its potential consequences (Cincotta, Engelman \& Anastasian 2003; Urdal \& Hoelscher 2009); sustainable employment and employment opportunities - and the link between these and 'promotive-transformative' (Sumberg \& Okali 2013: 270). The dominant policy solutions have been framed in terms of agricultural development, i.e. investing in agriculture in order to incorporate and attract young people to the sector, even though such policy framing has been criticised for its lack of evidence and attention to context (Leavy \& Hossain 2014; Okali \& Sumberg 2012).

Despite the current attention on youth and agriculture, the underlying rationale is grounded in early agriculture-centred ideas of the 1960s (for example Schultz 1964). They have, in turn, been influenced by common narratives around youth, such as young people being seen as national assets (Okali \& Sumberg 2012) and the promotion of agrarian entrepreneurship as a solution to the youth problem (Langevang \& Gough 2012). These narratives have, however, often come to present youth as an unproblematic category, and in the words of Christine Okali 
and James Sumberg as a 'homogeneous group, undifferentiated ... and existing independently of families, communities and broader social relations' (2012: 44).

\section{The term 'youth' and the youth and agriculture problem}

\section{Defining youth in an African context}

Sociologically, 'youth' denotes an interface between childhood and adulthood; and in societies like those in rural Africa adulthood is largely determined by the capacity to sustain a 'legal' marriage (Abdullah 1998). In such societies, unmarried individuals are seen as having failed the transition from childhood to adulthood. In certain cultures, however, the transition is often associated with an individual having undergone and completed certain rituals that mark such an individual's new status as an adult (Thorsen 2007). It is, however, generally the case in policy terms that youth as a social group is defined in terms of an age bracket. Even here, there is little consensus, as various age capsules ( 14 to $25 ; 15$ to $24 ; 15$ to $29 ; 15$ to $30 ; 15$ to $35 ; 18$ to 35 ) are paraded by different institutions (Anyidoho, et al 2012). Most African countries have either adopted the UN categorisation of 15 to 24 or the Commonwealth definition of 15 to 29, although there has been a tendency to extend the category to 30 years and beyond in certain cases. For present purposes I will use young people and youth interchangeably to refer to individuals between 18 and 35 regardless of whether they are married or single.

\section{Youth, unemployment and employment in agriculture}

Amidst rising scholarly concerns with growing youth unemployment, many developing country governments and development agencies embraced employment generation and sustainable livelihoods for youth in the 2000s (Africa Commission 2009; World Bank 2006). In particular, this was an era of 'new wave' land reforms, but also, concerns over poverty and its reduction, empowerment and food insecurity in most poor countries, which became central policy issues for development institutions (see World Bank 2006). A host of documents and programmes by development and donor agencies, and donor-funded scholarship have put forward the view that agriculture has the potential to solve the world's youth crisis (Proctor \& Lucchesi 2012; White 2012). One key contribution of this era was Jan Douwe van der Ploeg's 2008 work, The New Peasantries: Struggles for Autonomy and Sustainability in an Era of Empire and Globalization, 
where he contested the notion of the demise of the peasantry, thus giving legitimacy to the emphasis on youth and agriculture.

Proponents of the 'agriculture as a solution to youth problem' argue that youth's involvement in agriculture - especially family or household farming activities - begins at an early age, 'but such work is mostly unpaid and controlled by other household members: it does not usually bring autonomy, at least in the short term' (Porter, et al 2010: 1091). This, they view as a major impediment to attaining an education, since the potential to escape agriculture is limited. However, these young people could be retained in the sector if the right policies to support that retention are implemented (for example White 2012). A good starting point for retention policy is seen to rest in capacity-building. There have been long-standing concerns over capacity issues in agriculture (people with capable skills, access to credit, and improved agricultural technology). These concerns, which have dominated thinking on small-farm agriculture over the years (for example Binswanger \& Deininger 1997; Deininger \& Byerlee 2011), often highlighted the growth and employment potential of modern and market-oriented agriculture. Such forms of agriculture have now emerged as 'the saviour of young people' (Sumberg, et al 2012: 3).

While in early postcolonial Africa there was much emphasis on large-scale state initiated agricultural projects, by the end of the century the shift in focus to small farms began to gain prominence with growing concerns on poverty reduction and employment (Deininger \& Byerlee 2011; Lipton \& Longhurst 2010). The key point was that agriculture as the biggest employer and a growing industry, if afforded sufficient support, had the potential to improve the well-being of many people, and could attract interest from young school leavers and college graduates. Ben White identified what he called 'the narrowing and sometimes complete closure of access to land', which he attributed to a number of reasons including:

... corporate or absentee acquisition of community land; the micro land grabs and 'intimate exclusions' resulting from local processes of everyday accumulation, land concentration and social divisions that are inherent in agro-commodity production; or simply local gerontocratic structures which give the older generation control of land resources, and make them reluctant to transfer this control to the next generation. (2012: 12) 
These, of course, together with other issues including education systems, tended to influence young people's dislike of and exit from agriculture. It is evident from contemporary studies on youth that both they and their parents do not hold agriculture in high esteem (Tadele \& Gella 2012). Instead, there is a general preference for formal jobs that have a steady income, and migration for work in urban centres has been a long established livelihood strategy in rural societies in Africa (Jeffrey 2010; Sumberg \& Okali 2013). The continued preference for nonfarm occupations is also evident in parents' investments in children's education and priorities for migration and status enhancement through occupation by young graduates (Leavy \& Smith 2010). Agriculture-based occupations, especially in the mostly drudgery manner in which it is performed in rural society, does not confer youth with such enhanced status. Jennifer Leavy and Naomi Hossain make critical observations on the effect of education:

Better education and communications appear to have had the effect of dramatising the hardships of a farming life: a generation has grown to adulthood which, in some of the less developed locations in particular, has for the first time had the means to compare a future as a farmer ... with other possibilities ... Many of these young people speak movingly about the sorrow they feel witnessing their small farmer parents' often desperately hard struggles to earn a living. (2014: 9)

In addition to these, there are other significant studies that have been conducted in migrant labour societies. In settler Africa, agricultural development - whether to shift from selfprovisioning to market-based production or to transform traditional to modern and technologybased systems - came rather late after capitalism had taken root (see Cousins \& Scoones 2010; Duggan 1980; Throup 1987; Wolmer \& Scoones 2000). Central to the history of capitalism in these countries was labour migration to mines and industries and commercial farms, and structurally this was often seen to have resulted in the development of a worker-peasantry (Bernstein 2004; Potts 2000). These derived their identity from their involvement in non-farm activities while at the same time maintaining rural land (see Bernstein 2004; Boehm 2003; Cousins, Weiner \& Amin 1992; Potts \& Mutambirwa 1990). As Ronald Berkvens notes:

Men function as breadwinners on the basis of some form of non-agricultural employment. Women may regard themselves as housewives with control over household's assets and responsibility for subsistence tasks and the education of children. (1997: 6) 
This development was amply captured by Cordell, Gregory and Piché in their 1996 work, Hoe and Wage: A Social History of a Circular Migration System in West Africa. Such labour fragmentation through 'combinations of hoe and wage/wage and hoe, of farming and (migrant) wage employment' has tended to blur such 'conventional and pervasive distinctions/separations as "urban" and "rural", "worker" and "farmer"” (Bernstein 2004: 211).

A number of publications have expounded on the migrant labour system in southern Africa, its implications for the development of capitalism, and its exploitative character (Arrighi 1970; Wolpe 1972). The system was designed to suit the needs of capital, which needed labour at cheaper rates. Deborah Potts has pointed out the exploitative dimension, arguing:

... the system rested on migration being circular between rural areas and urban centres, and on migrants retaining access to rural land (which should, however, be insufficient to generate enough income to meet all a family's needs). (2000: 811)

The resultant conditions have often been associated with agricultural failure in some rural societies as most households became highly dependent on remittances from the capitalist sector (see Potts 2000; Potts \& Mutambirwa 1990; GoL [Riddell Commission] 1981; Yudelman 1964). Variation between regions existed and even between communities, and where agriculture was less successful, labour migration became a livelihood and survival strategy. In the short to long run, labour migration brought substantial incomes to households and began to inform investment decisions and social differentiation (Cousins, et al 1992; Murray 1981). With time, the system became deeply embedded in rural society so that attempts to end it in countries like Zimbabwe have been unsuccessful (Bush \& Cliffe 1984; Duggan 1980; Thompson 2004). Ray Bush \& Lionel Cliffe (1984) referred to countries that gained independence a little earlier - Botswana, Lesotho, Malawi and Swaziland - where labour migration (whether internal or in the form of labour exports) continued after achieving independence. Although Cousins, et al (1992) once predicted the demise of a worker-peasantry in Zimbabwe, recent scholarship on migration attest to its perversity (Berkvens 1997; Thebe 2011, 2012, 2014).

But, the most significant contribution of labour migration was the process of deagrarianisation. In Lesotho, Christian Boehm observed, '[r] ural households prime attention was, and still is, geared towards jobs - not farming' (2003: 5). The whole system was highly gendered, with agriculture being feminised while men's place was outside agriculture where they 
were supposed to make money. In a way, this paved a way for labour migrants to invest in children's education, and as noted earlier, studies show that after going through the education system young people tend to aspire for high status occupations rather than agriculture (Biriwasha 2012; Leavy \& Hossain 2014).

\section{Youth and agriculture in Zimbabwe}

In Zimbabwe, where the majority of young people are introduced into agriculture at a tender age through household subsistence production and the school curriculum (Biriwasha 2012), the solution to the youth problem, particularly in rural areas, is seen to lie in agricultural development (see Chidoko \& Zhou 2012). This is understandable in a context where youth unemployment and economic crisis are permanent features of Zimbabwe's economic landscape, and opportunities for survival remain only in the agriculture sector (see Chagwiza, et al 2012; Chidoko \& Zhou 2012). However, whether agriculture can fulfil these expectations remains a subject of intense debate. Conflicting views on agriculture and youth continue to dominate literature on youth and agriculture in Zimbabwe (for example Biriwasha 2012; Chidoko \& Zhou 2012; Nyoni 2012). While few dispute the potential of agriculture in employment provision in rural areas, a substantial amount of scholarly literature has highlighted the deagrarianisation of youth in Zimbabwe.

The disappearing youth from the rural farm sector and youth preference for non-farm occupations has been blamed on a horde of factors including the low status of agriculture, and therefore, the comparative advantage of non-farm occupations to on-farm jobs (Low 1986) and the lack of investment in the sector (Chidoko \& Zhou 2012). Literature has commented on the system of labour migration, which tended to exploit women, children and the youth in the absence of labour migrant men (Chinyemba, Muchema \& Hakutangwi 2006; Kawewe 2007; Potts 2000). Chinyemba, et al (2006) have pointed out that the withdrawal of male labour from agriculture induce an overreliance on children for on-farm tasks, and the high incidence of poor households to withdraw children from school to compensate for male labour. The situation referred to by Chinyemba, et al (2006) is most common in communal Zimbabwe where male members command the labour of both women and children.

However, the involvement of children and youth in agriculture has a long pedigree in Zimbabwe and can be traced to pre-colonial societies: As Beverley Grier once commented: 
Men and older boys (sons, servants) were responsible for clearing the land and preparing it for planting. Women and girls (wives, daughters, servants) were responsible for most of the other tasks associated with agricultural production: planting, weeding, and processing. Everyone, young and old, male and female, was involved in harvesting activities. Women and girls were responsible for most of the tasks around the household, including cooking, fetching water and fire wood, and caring for young children. Men were responsible for house building and mending and for the care of animals (cattle, goats, and sheep). They were assisted in the latter task by boy herder. (1994: 31)

Others have shown that children and young unmarried men were an integral part of the colonial economy, and were mainly utilised in commercial agriculture (see Grier 1994; Guy 1987). Their participation was either rewarded or they were simply regarded as appendages of their mothers (Grier 1994). Despite this rich history of involvement in agriculture, literature has also documented how the modern sector tend to draw children and young people away from agriculture into schools and the non-farm wage sector (Berkvens 1997; Nyoni 2012; Thebe 2012, 2014). While perceptions and attitudes towards agriculture-based occupations are central to the deagrarianisation of youth, others have shown that the perceptions of youth towards agriculture are not homogeneous and are therefore difficult to generalise. Tavaka Nyoni (2012), in particular, noted differences between young people in good rainfall regions and those in drier areas like Matabeleland where commercial crop production is often hindered by harsh weather conditions and poor soil quality. In good to moderate rainfall regions, youth engage in successful small-scale market-oriented agriculture, producing high value crops and are organised into various agricultural associations (Nyoni 2012). In a different fashion, literature on urban agriculture highlights the increasing entry of young people into urban agriculture either through madiro or renting of land from the city council or private individuals (see Chagwiza, et al 2012). Two factors appear to have influenced youth entry into urban agriculture: (a) subsistence and survival in the face of growing poverty and unemployment and (b) as a hobby (usually for the rich), but in both cases crops may be consumed or sold.

\section{Land reform and youth in Zimbabwe (1980-2000)}

The land reform programme, launched in 1980 and implemented over two decades, was a complex political process with a multiplicity of objectives. Chief among these was the resolution of the land question - to resolve the skewed land distribution patterns where a minority owned 42 per cent of the country's prime land (Moyo 1995; Palmer 1990). However, efforts to achieve 
this were complicated by numerous factors including a restrictive framework, capacity constraints, and a changing political environment towards the year 2000 (Moyo 1995; Worby 2001).

Initially, land reform was expected to satisfy both the social and productivity goals (see Nkomo 1984). The policy arose against the background of severe overcrowding in communal areas and land needs for guerrillas and refugees. However, land was also expected to be productively utilised for both farmer and national development (Geza 1986; Nkomo 1984). These competing imperatives were reflected in the settler selection criteria adopted soon after independence: people or families that were effectively landless; unemployed individuals and poor families in the 18 and 55 age range with dependents prepared to forego all land rights in communal areas; returning Zimbabwean refugees; productive communal area farmers who were prepared to forego communal land rights and give-up any paid employment; and communal farmers holding Master Farmer certificates.

These beneficiary categories were open, and theoretically young people could qualify for land through some of these, but in reality they were unlikely to access such land. First, in Zimbabwe any selection criterion that focuses on farming competences generally disadvantages young people who generally lack farming acumen and agricultural resources. Second, young people are more likely to hold formal jobs or have aspirations for formal work, and are unlikely to access land even under the 'unemployed individuals and poor families within the 18 and 55 age range'. Last, but related to the two points above, land is mostly allocated to nuclear rather than whole families, which effectively leads to the disintegration of families, and in the context of a decades-old culture of interdependence, either through mutual aid or flow of resources towards and from family structures, young people are reluctant to leave the broader extended family (see Potts \& Mutambirwa 1990).

In policy terms therefore, youth were never an explicit target category. This was different to the cases of ex-combatants and refugees, where the policy was less ambiguous. Although some young people in particular places may have held hopes of benefiting from land redistribution, these hopes were frustrated by capture of the process by elites leading to a major policy shift towards the development of a black agrarian class in the 1990s (Moyo 1995; Sachikonye 2003). However, at the approach of the new millennium, the state was confronted with growing unemployment from mostly young people, widespread demonstrations by urban 
residents and rural land occupations. These together with emerging political pressures helped to shape the land reform direction and the launch of a second phase of land reform (LRRP II). At this point, the qualification criteria for resettlement was expanded to include retrenchees, and special categories of people - women, ex-combatants, agricultural graduates, master farmers, exfarm workers and persons of means and ability who intended to engage in agriculture. Implicit in the reworking of these categories, though not without problems, was the assumption that youth would be accommodated in any of the new categories. Two resettlement models were unveiled, an A1 model for small farmers and the medium/large-scale A2 model for agriculture entrepreneurship.

While in policy terms youth remained invisible, on the ground their visibility became more pronounced in 2000, and they began to assume a central role in the country's land politics. They together with war veterans virtually usurped the role of gazetted state institutions responsible for beneficiary selection, and turned the land reform exercise into a political party process, taking over the selection procedure, and orchestrating invasions and occupations of commercial farms (Chaumba, et al 2003). Scholarship has emphasised the political nature of these land occupations, and particularly the use of youth by politicians in need of specific commercial properties. Thus, youth were unleashed to champion the entrepreneurial ambitions of elites, but they were never assigned an allocation quota as a category. This set them apart from the war veterans, who were allocated a 20 per cent quota in every A1 resettlement village.

\section{Youth dynamics and landing the economy}

Many issues - loss of urban-based livelihoods, unemployment and land needs for new households - made a case for land for youth. In semi-arid regions, where the province of Matabeleland North will provide a stage for households' life histories on the youth/agriculture problem, my purpose was not to study land and agriculture, but to understand the young people, land and agriculture in relation to the semi-proletarianisation of livelihoods. I focused on places where livelihood pathways through land and agriculture were presented to young people, and were either spurned or accepted. I explored two contrasting sites where such dynamics of youth land needs and aspirations played out, and the implication for land reform and the creation of economic opportunities for youth through agriculture as advocated in current youth policies. The first site, a communal area situated on the southern fringes of the former Shangani Reserves in 
Lupane District is about 180 kmetres northwest of Bulawayo. It is mainly a society of ethnic Ndebele, established after colonial evictions from 'white land' in the late 1940s. It is also a typically migrant labour society where livelihoods are based on both 'hoe and wage'.

The second, an A1 model resettlement scheme in Umguza District, is about 43 kilometres from Bulawayo. It was established after the implementation of the Fast Track Land Reform and Resettlement Programme (FTLRRP) following land occupations in 2000. It is a society of people drawn from diverse backgrounds including aspirant farmers, home seekers, labour migrants and former farm workers. It was established on former ranching enterprises, occupying land of differing quality, ranging from poor sandy soils to rich black loams. I conducted my life histories in 2014 and 2015, about ten years after my initial ethnography. This was also a period of recovery from the droughts in the 2000s, but in the former reserve droughts are perennial and even in years of good rains, harvest deficits are experienced. The resettlement villages were already in full-scale production: land reform had drawn to a close, a land audit had been completed, and land beneficiaries had all taken up their land offers.

The two sites were different in political, social and economic terms: the resettlement villages were political zones and core areas of Zanu-PF support, while the communal area was politically polarised. Compared to the resettlement villages, which were communities of strangers brought together by circumstances, the former reserve was a network of social relations, ranging from kin to long-term neighbours. In both sites the population of household heads was highly diverse - in age, gender, social status, education, religion, and places of origin - and households had different land needs. The majority of the household heads were men between 25 and 65 although de jure female heads of households were also well represented in the former reserve. On average, household sizes were bigger in the former reserve with a growing population of young male and de facto female heads of households, compared to resettled areas where the majority of household heads were of mature age. In livelihood terms, the majority of households in the former reserve received the bulk of support outside agriculture, whereas the resettlement villages were created as small farm commercial entities where settlers were expected to engage in productive and market-oriented farming. 


\section{Wage and hoe, land and livelihood dynamics}

Contrary to the popular caricature in Zimbabwe of a rural household that was involved in and depended on agriculture for livelihood and survival, most households in the former reserve engaged in both wage and hoe. Thus, the majority of young people were labour migrants or aspiring labour migrants, the second generation of initial settlers. People had arrived from different parts of the country, mostly attracted by the infrastructural facilities (schools and connecting roads to workplaces in Bulawayo) rather than agriculture potential. Among these was a proletarian class that held jobs in the emerging industries in Bulawayo. Some had retired, but had accumulated assets including livestock and ploughs, which set them on a path to a lumpen semi-peasantry. Others were between jobs, and came to the reserves to secure land rights before rejoining the urban proletarian ranks. Some got land in the reserves through networks (mainly colleagues at work who already owned land in the reserves). There were also others who held jobs locally. Maybe because of the long history of association with the world of capitalism, these people had come to define loafing in relation to non-involvement in the formal sector. In this society, ulova (loafer) defined non-labour migrants even if such people were engaged in agriculture.

At the time of the study, many of the young adults that were heads of households had inherited homes after the death of parents. There were also others that got land through intrahousehold land fission, allocation by headmen, madiro or vernacular land sales and rental markets. As noted elsewhere (Thebe 2012: 108), households commonly practised vernacular land sales and rental markets either to young communal members wishing to start their own homes or outsiders. Young men tended to want land for security rather than productive agriculture. They would 'book' the land, by leaving wives on the land supported by the extended family, to seek work in urban centres. The practice was well established before the 1990s (when the extended household institution was still dominant), however in the 2000s the strategy was not possible as the majority of extended families had disintegrated, and the tendency for most young men was to leave the home with the young wife, children and hired helpers. Younger and other migrant men oscillated between the rural home and the capitalist world: some were permanent labour migrants who spent the bulk of their time away and only paid occasional visits; others were loafers who only left the rural home for temporary jobs. Themba, for example was 32 and unemployed. He had lost his parents, and had inherited the land where he lived with his young 
wife and three children. He had relatives in the community including an older sister who had married locally, a younger brother, and other extended family members. His father had arrived in the area together with his older brother from peri-urban Bulawayo in the late 1950s. They both worked for the Bulawayo City Council. Themba, from Menyezwa, had also worked in Bulawayo before losing his job.

Very few young women were de jure heads of households with their own land, although a significant majority headed households de facto and had access to land. Cynthia, aged 28, for example had been abandoned by her husband who had remarried in South Africa. She was left with two children, the home and the family land. While she engaged in part-time farming, she also held a full-time job as the community health officer. Although there were other young women like Cynthia who headed households, most young women were married to labour migrants.

In general, the majority of young people were literate and some had completed secondary schooling. Many young people have knowledge about and skills in agriculture, as the government made sure it was part of the school curriculum in order to prepare young people for a future in farming. The state provided specialist teachers from the country's agriculture institutes who also acted as demonstrators in school gardens. In order to pass the final year exit examinations students were expected to complete a theory and practical test in agriculture. Despite all these efforts, young people graduating from school and those that had settled into married life had not put the knowledge gained from four years of education and demonstrations into practice. Themba reflected on his agriculture education:

We were taught to grow and care for crops, but this education is not helpful. To farm effectively, one needs favourable weather and not just land. These attempts are not new here ... I come from a farming background ... my family was part of the 'Master Farmer' scheme, but we never completely depended on farming. My father worked in the city, my uncle worked in the city, and the money came from the city, not agriculture. Conditions here are semi-arid. You need a reliable supply of water even for small green gardening. In our community we rely on boreholes, and these often breakdown ... when they breakdown and are not repaired immediately, crops are lost.

Although the young futures envisioned in agriculture by the postcolonial state failed to materialise in this area, as was the case elsewhere in semi-arid regions, it was hard to miss its wide acceptance by some non-state actors including non-governmental organisations (NGOs) 
that continued to distribute inputs, and to implement farming projects for young people. Victor (27), also from Menyezwa, who was part of a project in partnership with nine other young adults - four men and six women - had experienced the disappointments of these projects first hand:

You labour hard and gain very little. The market is available locally but this market cannot sustain the needs and requirements of ten adults. We live from hand to mouth with little prospects for growth. Because of these challenges people withdraw from the project to seek work elsewhere. Since we started in 2013, we have lost five members.

In typical labour migrant culture, these young people did not consider agriculture as an occupation. If they engaged in farming activities, they also demonstrated their perception and understanding of such practices by treating them as purely subsistence. Similar to findings by Boehm (2003) in Lesotho, the aspirations of young men in this community were not to farm, but to seek work once they left school. In the absence of formal jobs, they raised income through non-farm activities like building, crafts and menial village tasks. However, they abandoned all rural activities for opportunities in the formal sector when they became available and only returned at the end of the contract.

In the 2000s, livelihoods and employment for young people (both male and female) were centrally about cross-border migration to South Africa. Young men would marry and build homes and migrate to South Africa, leaving behind their young families. In this area the pull of South African had become intense for young people and nearly every household had a young person working there. The pulling factor, however, was not the status associated with working outside the country, but that of remittances and the accompanying investments that migrants made. The investments made from migration had in turn led to new forms of social differentiation, with migrant households occupying the upper hierarchy of society, and often seen as a model of rural affluence.

The young people working in South Africa made different kinds of investments, depending on the extent of their connection to the rural home. Those that left behind wives and children tended to invest in both moveable and immovable assets, more so than people who had no immediate families in the communal area. Raymond, for example, had invested in cattle, a herd of donkeys, a scotch cart, and had hired additional help for his young family. He worked in South Africa as a freelance carpenter and spent most of his time away from home. He owned 
land and engaged in farming with his young family, relatives and helpers. However, even with his assets, he did not see himself engaging in full-time farming. As he put it, '... it is difficult to support a family through farming'.

The kind of evidence on land, agriculture and livelihoods from this case study makes the motivation for 'landing the economy' for youth appear rather static, just as it calls into question the blind faith in standard models of resettlement where land fission for young families is difficult to achieve. The culture that had developed in these communities meant that people, both young and old, were not in a position to begin a new life as farmers. To pursue this argument further, I will turn to the question of the Sotane Ranch south of the Gwayi River. The Sotane Ranch was a major employer for men in the surrounding villages until the initial owner, who was a successful rancher, was killed by guerrillas in 1977. After his death different owners came and left until the land was finally allocated to a business consortium as an A2 model wildlife conservatory in 2000. In between these different owners, the ranch lay vacant allowing villagers to poach-graze their livestock and harvest other resources. Because of such access these villages literary assumed de facto ownership of the ranch for long periods.

Two elements made the ranch particularly attractive for occupation by would-be farmers. First, the soil was rich and suitable for crops produced in the region. Maize, for example was the most common crop produced by households, and in this soil it could be produced without applying organic manure and chemical fertilizers. Second, there was latitude for madiro since land was readily available. In the communal area, where people lived and farmed, land was degrading rapidly, fields were lost to soil exhaustion and there was a growing demand for land by new households. While we would expect people to occupy the ranch in line with madiro, they showed no interest towards the ranch, preferring instead, to limit new land occupations within the settlements. New settlements clearly increased from the late 1980s as young members of households and others from outside established homes, but these developments occurred on fallow and pasture land. As Mandla Ngwenya (34), from Menyezwa, concurred:

People settled on fallowed land or land released for pastures. ....there was never any consideration to settle on the ranch. The ranch offered a range of resources including grazing... people would graze their cattle, harvest grass and wood....but no one ever ploughed the land. 
The failure of the community, and young people in particular, to lay claims on the vacant ranch was particularly surprising given the growth in population, communal land degradation and erosion, and loss of local employment opportunities. This, however, may explain the possibility that land for productive farming was never a feature in these communities, and probably never will; if young people sought land, it was probably because they needed virgin land to engage in some subsistence production. When the waves of farm occupations started in 1999, significant differences emerged between the war veterans and the young people in the community. This was demonstrated by the lack of support for the occupation of the ranch. The local war veterans initiated an abortive occupation of the ranch in 2000 , but all other villagers stayed away, condemning the acts as politically motivated. To escape the wrath of war veterans, young men resorted to leaving the community briefly, and others for a much longer period. However, after aborting the occupation of the ranch, the war veterans turned their attention to farms in Umguza District. The farms proved particularly attractive to occupiers because of the rich soil, and their proximity to Bulawayo.

\section{Resettlement, young settlers and agriculture}

The occupation of farms, and the subsequent resettlement was guided by the narrative 'land is the economy and the economy land', which also underscored the case for petty commodity producers as equally productive. The resettlement areas were seen as places for a new agrarian class that would ensure food security and economic stability for the country. Certainly, this presented the Zimbabwean state with a perfect opportunity to solve the youth crisis: to attract youth to agriculture and empower them economically through land. Instead, land reform, if the process that followed could be conjured to qualify as such, was shifted towards the satisfaction of political goals and away from poverty reduction and economic empowerment concerns for poor categories.

Indeed, in the resettlement area in Umguza District, as was the case in other areas, war veterans became a politically too powerful group that ended up dominating all resettlement villages at the expense of other categories. More basically, war veterans far exceeded the 20 per cent official quota in all villages, although there was still a small minority of youth including young former farm workers and single women who had received land. It was widely claimed however that these young people owed their land to the political power of war veterans. They 
were allocated land for their active participation in and show of support for the initial occupations or as relatives to war veterans and other politicians. Until 2001 the state had limited control over occupied farms - giving war veterans and local politicians considerable influence over plot allocations through an occupation register where participants and their relatives were listed (see Chaumba, et al 2003). For example, of the 15 young settlers who participated in the study, eight had actively participated in the land occupations, four of the young single women got land through relatives, and three were former farm workers who had joined the initial land occupations.

While small-farm agriculture is highly dependent on one having draft power - a plough and other related inputs - most young settlers had no assets and had left relatives behind in the communal areas. They had all been involved in farm-related activities from a young age, and had access to land and resources from families and other kin networks in the communal areas. Some were holding land for the first time in the resettlement area. There were some, however, who arrived in Umguza with relatives, and although they had no assets of their own they were mere extensions of the main households. In either case, resource pooling became critical, as it allowed those without assets to have their land cultivated. For example, Jonathan was aged 26 in 2006 and married. He had his own home and fields in a neighbouring village to that of his elder brother who was a war veteran. Before moving to the resettlement areas, the two brothers had lived together, worked the field together and ate together. His elder brother owned a herd of cattle and donkeys, a plough and cultivator, and was also taking care of their mother and younger siblings. Jonathan helped in looking after the cattle and preparing fields - both his elder brother's and his own - and in return he had unrestricted access to these assets. While his land allotment was fully utilised, his elder brother was using two acres of the land to grow his own sunflower and maize crops.

Labour for on-farm tasks was a major challenge even for large households in the absence of the labour of children who attended school outside the resettlement zone. It is then obvious why resource pooling assumed increased importance for families with young children, for agricultural tasks could not be achieved without additional labour. These young settlers were often not able to farm their land, to the irritation of war veterans, who were acting as de facto government monitors at the resettlement level. Many recognised the differences in terms of access to labour between resettlement and communal areas where they could draw on kin 
networks or organise ilima (community resource pooling scheme): at the same time they were compelled to work in other people's fields as part of the resource pooling arrangement.

MaMpofu (26), a young wife from Umguza, recalled these difficulties:

... here, you are virtually alone ... no relative, no neighbour to assist you. We work our fields, work their fields and still, we are expected to plough all our fields. These fields are too big for a small family. In rural areas we brewed beer and invited neighbours to assist with on-farm tasks.

Before relocating to the resettlement farms, almost all young families had support structures in the form of extended family members at their places of origin, and could afford to spread risks by allowing males to seek paid work. MaNyoni (29), from Umguza, noted:

$\ldots$ in the resettlement villages the emphasis is on putting land into productive use as a condition for us to keep our land and this makes it impossible for risk spreading strategies ... these conditions are proving to be a major source of food insecurity [indlala] for us since there are little possibilities for fragmenting labour and diversifying livelihoods.

It was not simply that only young families were struggling to cope, but single young women also fell into this category. They had hired people to reside and work on their land while they continued living in the cities, and were by far the most unproductive. As a whole, there is little doubt that young people were failing to honour the expectation of their new environment, as none had taken maize to the Grain Marketing Board since resettlement in 2000. Most young families got caught between the competing needs to secure land rights and livelihood security. To secure land rights they would engage in vernacular land leases - leasing part of their land to others. Instances also occurred where men from these households migrated to the city or South Africa, leaving behind wives as de facto heads of households. In 2014 when I conducted my life histories, four of the 15 young men I had met in 2005 said they performed occasional work in neighbouring A2 farms, five had done work outside agriculture since moving into the resettlement village, and six had left the farms for South Africa.

Nkululeko, aged 33 and married with three children, provides a good example. He originated from eastern Lupane District, where he had lived with his parents and young wife. He had never owned land of his own. After his secondary school, he had worked for a logging company. He had also worked in Bulawayo. In 1999 when the land occupations started, he 
joined the war veterans from his area in occupying the Redwood Ranch where he was allocated land. In 2004, he had only built two rudimentary huts and was using a part of the residential plot for crop production. He had not cleared his allotment of fields, which he later leased to two of his neighbours. In 2006 he left for South Africa, leaving his wife behind. It would appear that he used the opportunity to improve his home by investing in a modern cement brick house, four cattle, ox-drawn plough and modern household furniture. In 2014, two of his daughters were attending secondary school outside the community and he had hired a male helper.

It is essential to note that young families were far worse in terms of livelihoods and welfare when they focused entirely on farming than when they started fragmenting labour. This was not surprising in the context of a decades-old culture of 'hoe and wage', and the risks associated with agriculture-based livelihoods. In the Matabeleland region, the years after 2000 were characterised by successive droughts, and in the absence of irrigation infrastructure, which was destroyed at occupation, households experienced perennial crop failure. While perennial harvest failure was bounded to the settlers' agricultural systems, it was also tied to the state's lack of capacity and post-settlement support. Young families were unable to make any investment into farming, and needed state support through the provision of inputs, credit and extension services. However, whatever support was available was confined to neighbouring medium/large-scale farmers on the A2 models. All land settlers had received minimum support from the state since 2000 .

On the farms, there was support in agricultural extension given to resettled farmers but none of these households had engaged extension services. Arrangements could also be made for tractors from the District Development Fund (DDF), yet none of the farmers had been successful in applying for the tractors since they were always unavailable. I was informed by Moses (31), from Umguza, 'these tractors were either broken down, busy elsewhere or there was no diesel'. Loans could also be obtained from the Agriculture Bank to ensure farmers would invest in farming, but even for those who had applied, loans had not been received in 2006. And even the inputs loan that was launched in 2003 later collapsed following persistent droughts and defaults before some households could gain access. These challenges forced most young families to abandon any aspirations, if ever they had any, of farming. 


\section{Conclusion}

The completion of the FTLRRP was an ambiguous victory for indigenous Zimbabweans. The concern with the historical past and the political imperative for reform drew attention to the changes in the agrarian structure, and ultimately obscured the degree to which, for some youth, the new social relations and patterns of accumulation reinforced processes of exclusion and impoverishment. Although I recognise land reform as a key dimension of agrarian reform and empowerment, I am also cautious about such effects, particularly in a context such as Zimbabwe where certain historical and social dynamics coalesced to denigrate agriculture-based livelihoods. As my ethnography has shown, young people were mostly second generation labour migrants, and farming was not what they aspired to, even if they wished to acquire land. Presumably, it was their conscious realisation that productive farming was far from being their preferred livelihood pathway.

In resettlement areas, we saw a replay of those conditions described by Feldman, Geisler \& Silberling, where the youth and others without resources, lost 'access to established kin networks' that had previously provided the 'context for routine social activities, collective identities, and subsidies that assist them during times of stress' (2004: 9). A focus on agriculture performance portrayed young land beneficiaries as resource poor, disinterested in agriculture and only interested in safeguarding their land rights. The most illustrative case in point was the vernacular land leases to neighbours and incidents of agriculture disengagement in search of livelihood security elsewhere. These incidents rule out the possibility of economic well-being through land, and render a policy of agricultural modernisation unlikely to succeed in changing the economic circumstances of youth. Perhaps in migrant labour societies, semiproletarianisation had come to define how young people view land and livelihoods. By examining politico-social dynamics and their intersection with the particular subject of land reform and youth, it became apparent that landing the economy was not ideal for youth economic empowerment, and could not provide youth with the livelihood security they aspire to. In migrant labour societies youth had land needs and livelihoods that were diametrically opposed to state land reform objectives. Farming was the least of young people's livelihood aspirations. Assuming therefore, that behaviour at both communal area and resettlement farm level was a true representation of the realities of young people in Zimbabwe, this has certain implications for 
how future land-based livelihood models should be designed to accommodate the younger generation.

\section{References}

Abdullah, I. 1998. 'Bush path to destruction: The origin and character of the Revolutionary United Front/Sierra Leone'. Journal of Modern African Studies 36(2): 203-34.

Africa Commission. 2009. Realising the Potential of Africa's Youth: Report of the Africa Commission. Copenhagen: Ministry of Foreign Affairs of Denmark.

Anyidoho, N.A., Kayuni, H., Ndungu, J., Leavy, J., Sall, M., Tadele, G. \& Sumberg, J. 2012. 'Young people and policy narratives in sub-Saharan Africa'. Future Agricultures Working Paper 032. Brighton: IDS.

Arrighi, G. 1970. 'Labour supplies in historical perspective: A study of the proletarianization of the African peasantry in Rhodesia'. Journal of Development Studies VI: 198-233.

Berkvens, R.J.A. 1997. 'Backing two horses: Interaction of agricultural and non-agricultural household activities in a Zimbabwean communal area'. Working Paper 24. Leiden: De-agrarianisation and Rural Employment Network.

Bernstein, H. 2004. "“Changing before our very Eyes": Agrarian questions and the politics of land in capitalism today". Journal of Agrarian Change 4(1\&2): 190- 225

Binswanger, H.P. \& Deininger, K. 1997. Explaining Agricultural and Agrarian Policies in Developing Countries. Washington: World Bank.

Biriwasha, L. 2012. 'Agriculture and the school curriculum in Zimbabwe'. International Conference on Young People, Farming and Food: The Future of the Agrifood Sector in Africa, 19-21 March, Accra.

Boehm, C. 2003. 'The social life of fields: Labour markets and agrarian change in Lesotho'. Paideusis Journal of Interdisciplinary and Cross-cultural Studies 3: 1-20.

Bush, R. \& Cliffe, L. 1984. 'Agrarian policy in migrant labour societies: Reform or transformation in Zimbabwe?' Review of African Political Economy 29: 77-94.

Chagwiza, G., Zivenge, E., Chivuraise, C., Munyati, V. \& Musara J.P. 2012. 'An assessment on factors affecting urban vegetable production in Harare, Zimbabwe'. Global Advanced Research Journal of Agricultural Science 1(8): 210-15.

Chaumba, J., Scoones, I. \& Wolmer, W. 2003. 'From jambanja to planning: The reassertion of technocracy in South-eastern Zimbabwe?' Journal of Modern African Studies 41(4): 533-54.

Chidoko, C. \& Zhou, S. 2012. 'Impact of agricultural development on youth employment in Zimbabwe: The case of Masvingo Province'. Russian Journal of Agricultural and Socio-Economic Sciences 11: 24-7.

Chinyemba, M.J., Muchema, O.N. \& Hakutangwi, M.B.K. 2006. 'Women and agriculture', in R. Rukuni, et al (eds), Zimbabwe's Agricultural Revolution Revisited. Harare: University of Zimbabwe Publications.

Cincotta, R.P., Engelman, R. \& Anastasian, D. 2003. The Security Demographic: Population and Civil Conflict after the Cold War. Washington: Population Action International.

Cordell, D.D., Gregory, W.J.W. \& Piché, V. 1996. Hoe and Wage. A Social History of a Circular Migration System in West Africa. Boulder: Westview Press.

Cousins, B. \& Scoones, I. 2010. 'Contested paradigms of "viability" in redistributive land reform: Perspectives from southern Africa'. Journal of Peasant Studies 37(1): 31-66.

Cousins, B., Weiner, D. \& Amin, N. 1992. 'Social differentiation in the communal lands of Zimbabwe'. Review of African Political Economy 19(53): 5-24.

Deininger, K.W. \& Byerlee, D. 2011. Rising Global Interest in Farmland: Can it Yield Sustainable and Equitable Benefits? Washington: World Bank Publications.

Duggan, W.R. 1980. 'The Native Land Husbandry Act of 1951 and the rural African middle class of Southern Rhodesia'. African Affairs 79(315): 227-340.

Feldman, S., Geisler, C. \& Silberling, L. 2004. 'Moving targets: Displacement, impoverishment, and development'. International Social Science Journal 55: 7-13.

Geza, S. 1986. 'The role of resettlement in social development in Zimbabwe'. Journal of Social Development in Africa 1: 35-42.

GoL [Riddell Commission]. 1981. Report of the Commission of Inquiry into Incomes, Prices and Conditions of Service. Harare: Government Printers. 
Grier, B. 1994. 'Invisible hands: The political economy of child labour in colonial Zimbabwe, 1890-1930'. Journal of Southern African Studies 20(1): 27-52.

Guy, J. 1987. 'Analysing pre-capitalist societies in southern Africa'. Journal of Southern African Studies 14(1): 1837.

Jeffrey, C. 2010. Timepass: Youth, Class and the Politics of Waiting in India. Stanford: Stanford University Press.

Kawewe, S.M. 2007. 'Disenfranchisement of Zimbabwean women in public policy and national machinery undermines human rights, social development, peace and social justice', in O. Wusu (ed), Politics and Economics of Africa Volume 5. New York: Nova Publishing.

Langevang, T. \& Gough, K.V. 2012. 'Diverging pathways: Young female employment and entrepreneurship in subSaharan Africa'. Geographical Journal 178(3): 242-52.

Leavy, J. \& Hossain, N. 2014. 'Who wants to farm? Youth aspirations, opportunities and rising food prices'. IDS Working Paper 439. Brighton: IDS.

Leavy, J. \& Smith, S. 2010. 'Future farmers: Youth aspirations, expectations and life choices'. IDS Discussion Paper. Brighton: IDS.

Lipton, M. \& Longhurst, R. 2010. New Seeds and Poor People. London: Routledge.

Low, A. 1986. Agricultural Development in Southern Africa - Farm Household Economics and the Food Security Crisis. London: James Currey.

Manby, B. 2002. 'Zimbabwe - Fast Track Land Reform in Zimbabwe'. Human Rights Watch. A: Sub-Saharan Africa 14(1). New York: HRW.

Moyo, S. 1995. The Land Question in Zimbabwe. Harare: SAPES Books.

Murray, C. 1981. Families Divided: The Impact of Migrant Labour in Lesotho. Cambridge: African Studies Series.

Nkomo, J.M. 1984. The Story of my Life. London: The Chaucer Press.

Nyoni, T. 2012. Current and Emerging Youth Policies and Initiatives with a Special Focus on Link to Agriculture. Pretoria: Food, Agriculture and Natural Resources Policy Analysis Network.

Okali, C. \& Sumberg, J. 2012. 'Quick money and power: Tomatoes and livelihood building in rural BrongAhafo, Ghana'. IDS Bulletin 43(6): 44-57.

Palmer, R. 1990. 'Land reform in Zimbabwe, 1980-1990'. African Affairs 89(355): 163-81.

Porter, G., Hampshire, K., Mashiri, M., Dube, S. \& Maponya, G. 2010. "“Youthscapes” and escapes in rural Africa: Education, mobility and livelihood trajectories for young people in Eastern Cape, South Africa'. Journal of International Development 22: 1090-101.

Potts, D. 2000. 'Worker-peasants and farmer-housewives in Africa: The debate about "committed" farmers, access to land and agricultural production'. Journal of Southern African Studies 26(4): 807-32.

Potts, D. \& Mutambirwa, C. 1990. 'Rural-urban linkages in contemporary Harare: Why migrants need their land?' Journal of Southern African Studies 16(4): 677-98.

Proctor, F. \& Lucchesi, V. 2012. Small-scale Farming and Youth in an Era of Rapid Rural Change. London/The Hague: IIED/HIVOS.

Rutherford, B. 2008. 'Conditional belonging: Farm workers and the cultural politics of recognition in Zimbabwe'. Development and Change 39(1): 73-99.Sachikonye, L.M. 2003. 'From "Growth with Equity" to "fast track” reform: Zimbabwe land question'. Review of African Political Economy 30(96): 227-240.

Schultz, T.W. 1964. Transforming Traditional Agriculture. New Haven: Yale University Press.

Sumberg, J., Anyidolo, N.A., Leavy, D., Lintelo, D. \& Wellard, K. 2012. 'The young people and agriculture "problem" in Africa'. IDS Bulletin 43(6): 1-8.

Sumberg, J. \& Okali, C. 2013. 'Young people, agriculture, and transformation in rural Africa: An "opportunity space” approach'. Innovations, Special Issue for the 2013 Global Youth Economic Opportunities Conference, 10-12 September.

Tadele, G. \& Gella, A.A. 2012. 'A last resort and often not an option at all: Farming and young people in Ethiopia'. IDS Bulletin 43(6): 33-43.

Thebe, V. 2011. 'From South Africa with love: The "Malayisha" System and Ndebele households' quest for livelihood reconstruction in South-western Zimbabwe'. Journal of Modern African Studies 49(4): 647-70.

Thebe, V. 2012. 'New realities and tenure reforms: Land-use in worker-peasant communities of South-western Zimbabwe (1940s-2006)'. Journal of Contemporary African Studies 30(1): 99-117.

Thebe, V. 2014. 'New social formations, livelihood transition and food insecurity in worker-peasant communities'. Journal of Developing Societies 30(1): 45-67.

Thompson, G. 2004. 'Cultivating conflict: Agricultural "betterment”, the Native Land Husbandry Act (NLHA) and ungovernability in colonial Zimbabwe, 1951-1962'. African Development XXIX(3): 1-39. 
Thorsen, D. 2007. 'If only I get enough money for a bicycle! A study of childhoods, migration and adolescent aspirations against a backdrop of exploitation and trafficking in Burkina Faso'. Working Paper T21. Sussex: DRCMGP.

Throup, D. 1987. The Economic and Social Origins of Mau-Mau, 1945-1953. London: James Currey.

Van der Ploeg, J.D. 2008. The New Peasantries: Struggles for Autonomy and Sustainability in an Era of Empire and Globalization. London: Earthscan.

Urdal, H. \& Hoelscher, K. 2009. 'Youth bulges and social disorder: An empirical study of Asian and sub-Saharan African cities'. World Bank Policy Research Working Paper 5110. Washington: World Bank.

White, B. 2012. 'Agriculture and the generation problem: Rural youth, employment and the future of farming'. IDS Bulletin 43(6): 9-19.

Wolmer, W. \& Scoones, I. 2000. 'The science of "civilized" agriculture: The mixed farming discourse in Zimbabwe'. African Affairs 99: 575-600.

Wolpe, H. 1972. 'Capitalism and cheap labour-power in South Africa: From segregation to apartheid'. Economy and Society 1(4): 425-56.

Worby, L.E. 2001. 'A redivided land? New agrarian conflicts and questions in Zimbabwe'. Journal of Agrarian Change 1(4): 475-509.

World Bank. 2006. World Development Report 2007: Development and the Next Generation. Washington: World Bank.

Yudelman, M. 1964. Africans on the Land. Cambridge: Harvard University Press. 